\title{
THE STRUCTURE OF MOTOR SKILLS AMONG THE STUDENTS AT THE FACULTY OF SECURITY STUDIES
}

Original Scientific Paper

\begin{tabular}{|l|l|l|}
\hline DOI 10.7251/ZBKEN1901069P & COBISS.RS-ID 8275224 & UDK 572.512-057.875
\end{tabular}

\section{Darko Paspalj ${ }^{1}$}

Faculty of Security Studies, University of Banja Luka

Milan Guzvica

Faculty of Security Studies, University of Banja Luka

Lazar Vulin

Kozice Elementary School, Ostra Luka

Abstract: A system of 16 motor variables was used to determine the structure of motor skills in a sample of 84 students at the Faculty of Security Sciences in Banja Luka. By using factor analysis according to the Kaiser-Guttman rule, 6 latent motor dimensions were determined. The first factor is defined as the factor for the structuring movement mechanism, because it is presented with the variables used to assess coordination and movement frequency. The second factor is defined as the factor for the mechanism for regulating excitation duration, because it is represented by the measures used to assess the repetitive and static strength of arms, body, and legs. The third factor is defined as the factor for the tone regulation and synergistic regulation mechanism, because it is represented by the variables used to assess the measures of flexibility. The fourth factor is defined as the factor for the excitation intensity mechanism, because it is represented by the variable used to assess explosive power through the run speed capability. The fifth factor is also defined as the factor for synergistic regulation and tonus regulation, because it is represented by the variable used to assess balance, while the sixth factor is defined as the factor for excitation intensity, because it is represented by three variables used to assess explosive power and one variable used to assess flexibility. This paper is an attempt to demonstrate that the distinguished hierarchical structure of motor skills is of exceptional theoretical and practical value, whereby these factors should represent a determinant for predicting motor skills and programing operator training in special physical education classes.

Keywords: factor analysis, students, motor skills

\footnotetext{
${ }^{1}$ Corresponding author: Darko Paspalj, Assistant Professor, Faculty of Security Studies, University of Banja Luka. E-mail: darko.paspalj@fbn.unibl.org
} 


\section{INTRODUCTION}

The process of selection, guiding and monitoring in the field of special physical education (SPE) is unimaginable without information about the students' motor skills, indicating that in order to seriously program kinesiological operators, it is necessary to know the structure of motor skills, which are responsible for the efficiency of the motor behavior of the students at the Faculty of Security Sciences in solving complex situation-based and motor problems in conceptual and situational conditions. Motor skills are usually referred to in the literature as the characteristics of an individual expressing his or her physical preparedness to perform certain work and the ability to express his or her own personality creatively, which, in experimental research, are usually reduced to operatively defined latent dimensions derived from the measuring instruments. Previous research into the hierarchical functional model of motor skills (Zaciorski, 1975; Gredelj, Metikos, Hošek \& Momirović, 1975; Đorđević, 1989; Kukolj 1996) demonstrates that the hypothetical factors of the phenomenological model are defined in the first-order space, including coordination, strength, endurance, speed, flexibility, precision and balance, while, based on the research conducted by Kurelić et al. (1975), hypothetical factors are defined in the second-order space from the aspect of functional mechanisms, which include the mechanism for the structuring of movement, the mechanism for tone regulation and synergistic regulation, the mechanism for the regulation of excitation intensity, and the mechanism for regulating the duration of excitation. SPE as an element of the physical culture is aimed at perfecting psychosomatics in students through the achievement and maintenance of basic and special knowledge and skills (Blagojević, Dopsaj \& Vučkovcić, 2006), whereby well-defined educational and training programs should transform the general and special physical skills to meet the needs of law enforcement and other security agencies personnel (Milosevic, 1985; Milosevic \& Zulic, 1988; Milosevic, Gavrilovic \& Ivancevic, 1988; Blagojevic, Dopsaj \& Vuckovic, 1996, Vučković, 2002; Dopsaj, Milošević, Blagojević \& Vučković, 2002). The program activities of the SPE are part of the polystructural acyclic movement activities characterized by a multitude of technical elements, a rich tactical repertoire of actions, the diversity of movements of the whole body and some of its parts in different directions with varying strength and the intensity of action, whereby motor skills have a dominant role in relation to other adaptive characteristics (Milošević, Mudrić, Jovanović, Amanović \& Dopsaj, 2005). Bearing in mind the above issues, we may conclude that well-developed motor skills and the appropriate level of well-trained specific motor tasks are basic factors providing conditions for the successful performance of work by law enforcement and security agencies personnel (Milošević, 1985; Blagojević et al., 2006; Dopsaj et al., 2002). Given that the knowledge about the direction and intensity of the activity on the transformation of the psychosomatic status of students enables the appropriate and optimal programming of content knowledge for SPE, and that, based on the studies conducted so far, it has been established that motor 
skills substantially influence the efficiency of the acquisition and reception of SPE content knowledge, as well as the fact that SFO teaching significantly influences the transformation of students' motor skills, this study seeks to determine the hierarchical motor structure among the students at the Faculty of Security Sciences in Banja Luka in order to classify the students by motor skills into as homogeneous groups as possible, to increase efficiency in teaching SPE. Based on the research aim thus defined and the fact that it is a positive selection sample, we start with the assumption that the students at the Faculty of Security Sciences have the appropriate structure of motor skills, and that the factor analysis algorithm will transform the set of manifesting motor variables into the predicted number of relevant motor factors.

\section{METHODS}

\section{Sampling}

The sample consisted of 84 first-year male students at the Faculty of Security Sciences in Banja Luka, aged $19 \pm 0.6$ years. All the respondents constituting the sample were clinically healthy and without obvious morphological defects. The basic antropomorphological indicators of the sample tested accounted for TV $181.85 \pm 6.13 \mathrm{~cm}$, TT $78.25 \pm 9.19 \mathrm{~kg}$, and BMI $23.71 \pm 2.43 \mathrm{~kg} / \mathrm{m}^{2}$.

\section{Variable sampling}

Since it was not possible to include the entire area of motorics in this research, an attempt was made to analyze the structure of motor skills at the level of second-order factors with the representative measuring instruments for assessing the primary factors, whereby the motorics area was covered with the following 16 tests: hand tapping (MBFTAP), foot tapping (MBFTAN), agility on the ground (MAGONT), side steps (MAGKUS), one-legged stance on the balance platform (MBAP10), shoulder pass through (MFLISK), side lying leg raise (MFLOLB), toe touches standing on the bench (MFLPRK), standing long jump (MFESDM), a 20m standing-start sprint (MFE20V), throwing a midicine ball lying on the back (MFEBML), throwing a handball from the ground with legs spread (MFEBRL), flat bench press (MRABPT), weight sit-ups (MRCDTT), loaded half squats (MRLPCT), and a horizontal backrest (MSCHIL). All the variables used to assess motor skills possess the necessary metric characteristics (Metikos et al., 1989).

\section{DATA PROCESSING METHODS}

Statistical data processing was performed on the Pentium IV computer using the SPSS application (version 20.00). The basic measures of central tendency and dispersion results are defined using the arithmetic mean and 
standard deviation. In order to test the correctness of data distribution, the Kolmogorov-Smirnov test was used, while the testing of an alternative hypothesis was performed using a multivariate model of factor analysis, where the significance of the main components was determined using the Kaiser-Guttman rule. To determine the actual relations between the separated dimensions, the Oblimin rotation was used, after which the structure and complex matrixes were obtained.

\section{RESULTS}

Table 1 shows the descriptive parameters of the variables used to assess motor skills. The increased values of the standard deviation of the measures used to assess flexibility, explosive power, and strength indicate a high variability of the results around the arithmetic mean, but taking into account the sample size, this phenomenon may be regarded as normal. The results of the Kolmogorov-Smirnov test used to analyze the normality of the distribution demonstrate that most of the variables describe a normal distribution, while the values amounting to less than 0.05 were found for the variables used to assess coordination and balance (MAGONT, MAGKUS and MBAP10), as well as for the variables used to assess flexibility and strength (MFLOLB and MRCDTT).

Table 1. Basic descriptive parameters of the motor variables distribution

\begin{tabular}{ccccc}
\hline Variables & $\mathrm{N}$ & Mean & SD & $\begin{array}{c}\text { KS test } \\
\text { (significance) }\end{array}$ \\
\hline MBFTAP & 84 & 40.49 & 6.35 & 0.054 \\
\hline MBFTAN & 84 & 32.45 & 3.90 & 0.054 \\
\hline MAGONT & 84 & 12.87 & 3.70 & 0.002 \\
\hline MAGKUS & 84 & 9.24 & 1.40 & 0.021 \\
\hline MBAP1O & 84 & 3.71 & 2.96 & 0.002 \\
\hline MFLISK & 84 & 75.18 & 19.27 & 0.096 \\
\hline MFLOLB & 84 & 72.29 & 11.33 & 0.043 \\
\hline MFLPRK & 84 & 50.73 & 9.38 & 0.140 \\
\hline MFESDM & 84 & 248.73 & 15.16 & 0.844 \\
\hline MFE20V & 84 & 3.31 & 0.14 & 0.727 \\
\hline MFEBML & 84 & 130.00 & 18.19 & 0.224 \\
\hline MFEBRL & 84 & 190.00 & 32.71 & 0.677 \\
\hline MRABPT & 84 & 34.98 & 11.95 & 0.173 \\
\hline MRCDTT & 84 & 26.77 & 9.71 & 0.034 \\
\hline MRLPCT & 84 & 23.49 & 9.06 & 0.082 \\
\hline MSCHIL & 84 & 23.46 & 10.86 & 0.062 \\
\hline N & 84 & & & \\
\hline
\end{tabular}

Key: N - number of respondents; Mean - arithmetic mean; SD - standard deviation; KSp - the value of the probability of Kolmogorov-Smirnov test; MBFTAP - hand 
tapping; MBFTAN - foot tapping; MAGONT - agility on the ground; MAGKUS - side steps; MBAP1O - one-legged stance on the balance platform; MFLISK - shoulder pass through; MFLOLB - side lying leg raise; MFLPRK - pike stretch (on a bench); MFESDM - standing long jump; MFE20V - a 20m standing-start sprint; MFEBML - lying medicine ball throw; MFEBRL - seated handball throw (legs spread); MRABPT - flat bench press; MRCDTT - weight sit-ups; MRLPCT - half squats; MSCHIL - a horizontal backrest.

Table 2. Matrix of the inter-correlation of the variables used to assess motor skills

\begin{tabular}{|c|c|c|c|c|c|c|c|c|c|c|c|c|c|c|c|c|}
\hline & $\begin{array}{l}\sum_{i=1}^{0} \\
\sum_{i}^{m}\end{array}$ & 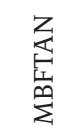 & $\begin{array}{l}5 \\
\text { 号 } \\
\text { 岁 }\end{array}$ & 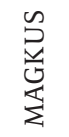 & $\underset{\substack{\infty \\
\sum}}{\stackrel{0}{z}}$ & 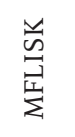 & $\begin{array}{l}\stackrel{\oplus}{\vec{O}} \\
\stackrel{\vec{I}}{\mathrm{I}}\end{array}$ & $\begin{array}{l}\underline{\underline{\alpha}} \\
\underline{a} \\
\sum_{\Sigma}\end{array}$ & 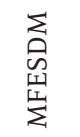 & 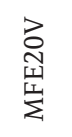 & 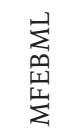 & 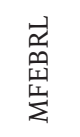 & 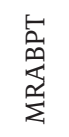 & 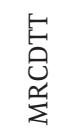 & 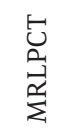 & 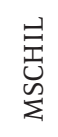 \\
\hline MBFTAP & 1.00 & & & & & & & & & & & & & & & \\
\hline MBFTAN & .213 & 1.00 & & & & & & & & & & & & & & \\
\hline MAGONT & -.277 & $7-.254$ & 1.00 & & & & & & & & & & & & & \\
\hline MAGKUS & -.289 & $9-.244$ & .617 & 1.00 & & & & & & & & & & & & \\
\hline MBAP10 & .022 & .011 & -.132 & -.146 & 1.00 & & & & & & & & & & & \\
\hline MFLISK & -.074 & $4-.089$ & -.029 & .009 & -.194 & 1.00 & & & & & & & & & & \\
\hline MFLOLB & .145 & .232 & .010 & -.097 & -.009 & -.435 & 1.00 & & & & & & & & & \\
\hline MFLPRK & .072 & -.013 & -.118 & -.173 & .113 & -.357. & .152 & 1.00 & & & & & & & & \\
\hline MFESDM & .164 & .157 & -.318 & -.235 & .200 & -.038. & .099 & .142 & 1.00 & & & & & & & \\
\hline MFE20V & .089 & -.042 & -.006 & -.030 & -.077 & -.087. & .083 & .082 & -.1811 & 1.00 & & & & & & \\
\hline MFEBML & .060 & -.072 & -.131 & -.049 & -.174 & $.024-$ & -.095 & .131 & $.178-$ & -.073 & 1.00 & & & & & \\
\hline MFEBRL & .169 & -.088 & $-101-$ & -.268 & .104 & -.100. & .068 & .351 & $.281-$ & -.102. & .326 & 1.00 & & & & \\
\hline MRABPT & -.089 & -.111 & .005 & .051 & -.061 & -.016 . & .011 & .053 & $-.082-$ & -.011. & .334 & .124 & 1.00 & & & \\
\hline MRCDTT & .114 & -.180 & $-.017-$ & -.038 & -.124 & .082 & .061 & .202 & $-.046-$ & -.060. & .253 & .099 & .454 & 1.00 & & \\
\hline MRLPCT & -.016 & -.067 & $-.147-$ & -.094 & .175 & -.236 . & .099 & .262 & $.083-$ & -.035 . & .139 & .200 & .311 & .273 & 1.00 & \\
\hline MSCHIL & -.016 & -.031 & $-.055-$ & -.086 & -.162 & $.060-$ & -.198 & .237 & .034. & .029. & .217 & .047 & .276 & .438 & .187 & 1.00 \\
\hline
\end{tabular}

Key: MBFTAP - hand tapping; MBFTAN - foot tapping; MAGONT - agility on the ground; MAGKUS - side steps; MBAP10 - one-legged stance on the balance platform; MFLISK - shoulder pass-throughs; MFLOLB - side laying leg raise; MFLPRK - pike stretch (on a bench); MFESDM - standing long jump; MFE20V - a 20m standing-start sprint; MFEBML - lying medicine ball throw; MFEBRL - seated handball throw (legs spread); MRABPT - flat bench press; MRCDTT - weight sit-ups; MRLPCT - half squats; MSCHIL - a horizontal backrest. 
Table 3. Matrix of characteristic roots and components of common variance explained

\begin{tabular}{|c|c|c|c|c|c|c|c|}
\hline \multirow{2}{*}{$\begin{array}{c}\text { Compo- } \\
\text { nents }\end{array}$} & \multicolumn{3}{|c|}{ Initial characteristic values } & \multicolumn{3}{|c|}{ The sum of square loadings } & \multirow{2}{*}{$\begin{array}{c}\text { Rotation } \\
\text { sums of } \\
\text { square } \\
\text { loadings } \\
\text { Charac- } \\
\text { teristic } \\
\text { roots }\end{array}$} \\
\hline & $\begin{array}{l}\text { Character- } \\
\text { istic } \\
\text { roots }\end{array}$ & $\begin{array}{c}\text { Variance } \\
\%\end{array}$ & $\begin{array}{c}\text { Cumu- } \\
\text { lative } \\
\text { sequence } \\
\%\end{array}$ & $\begin{array}{c}\text { Charac- } \\
\text { teristic } \\
\text { roots }\end{array}$ & $\begin{array}{l}\text { Vari- } \\
\text { ance } \\
\%\end{array}$ & $\begin{array}{c}\text { Cumula- } \\
\text { tive se- } \\
\text { quence } \\
\%\end{array}$ & \\
\hline 1 & 2.735 & 17.091 & 17.091 & 2.735 & 17.091 & 17.091 & 2.235 \\
\hline 2 & 2.275 & 14.216 & 31.307 & 2.275 & 14.216 & 31.307 & 2.249 \\
\hline 3 & 1.683 & 10.521 & 41.828 & 1.683 & 10.521 & 41.828 & 1.762 \\
\hline 4 & 1.355 & 8.469 & 50.297 & 1.355 & 8.469 & 50.297 & 1.233 \\
\hline 5 & 1.119 & 6.993 & 57.290 & 1.119 & 6.993 & 57.290 & 1.392 \\
\hline 6 & 1.063 & 6.643 & 63.933 & 1.063 & 6.643 & 63.933 & 1.921 \\
\hline 7 & .899 & 5.621 & 69.554 & & & & \\
\hline 8 & .834 & 5.211 & 74.765 & & & & \\
\hline 9 & .714 & 4.462 & 79.226 & & & & \\
\hline 10 & .662 & 4.140 & 83.366 & & & & \\
\hline 11 & .613 & 3.834 & 87.200 & & & & \\
\hline 12 & .571 & 3.570 & 90.770 & & & & \\
\hline 13 & .481 & 3.005 & 93.775 & & & & \\
\hline 14 & .423 & 2.643 & 96.419 & & & & \\
\hline 15 & .289 & 1.807 & 98.225 & & & & \\
\hline 16 & .284 & 1.775 & 100.000 & & & & \\
\hline
\end{tabular}


Table 4. Factor analysis of motor skills - the structure matrix

\begin{tabular}{|c|c|c|c|c|c|c|}
\hline \multicolumn{7}{|c|}{ The structure matrix } \\
\hline & 1 & 2 & 3 & 4 & 5 & 6 \\
\hline MAGONT & -.845 & & & & & \\
\hline MAGKUS & -.811 & & & & & \\
\hline MBFTAN & .522 & & .382 & & & -.357 \\
\hline MBFTAP & .515 & & & & & \\
\hline MRCDTT & & .783 & & & & \\
\hline MRABPT & & .766 & & & & \\
\hline MSCHIL & & .643 & & & & \\
\hline MRLPCT & & .554 & & & -.494 & \\
\hline MFLOLB & & & .870 & & & \\
\hline MFLISK & & & -.729 & & & \\
\hline MFE20V & & & & .829 & & \\
\hline MFESDM & .340 & & & -.413 & & .410 \\
\hline MBAP10 & & & & & -.796 & \\
\hline MFEBRL & & & & & & .839 \\
\hline MFEBML & & .311 & & & .356 & .557 \\
\hline MFLPRK & & & & .350 & & .505 \\
\hline
\end{tabular}

Key: MAGONT - agility on the ground; MAGKUS - side steps; MBFTAN - foot tapping; MBFTAP - hand tapping; MRCDTT - weight sit-ups; MRABPT - flat bench press; MSCHIL - a horizontal backrest; MRLPCT - half squats; MFLOLB - side lying leg raise; MFLISK - shoulder pass-throughs; MFE20V - a 20m standing-start sprint; MFESDM - standing long jump; MBAP10 - one-legged stance on the balance platform; MFEBRL - seated handball throw (legs spread); MFEBML - lying medicine ball throw; MFLPRK - pike stretch (on a bench). 
Table 5. Factor analysis of motor skills - the complex matrix

\begin{tabular}{|c|c|c|c|c|c|c|}
\hline \multicolumn{7}{|c|}{ The complex matrix } \\
\hline & 1 & 2 & 3 & 4 & 5 & 6 \\
\hline MAGONT & -.820 & & & & & \\
\hline MAGKUS & -.807 & & & & & \\
\hline MBFTAP & .558 & & & & & \\
\hline MBFTAN & .533 & & .406 & & & \\
\hline MRCDTT & & .789 & & & & \\
\hline MRABPT & & .754 & & & & \\
\hline MSCHIL & & .661 & & & & \\
\hline MRLPCT & & .546 & & & -.508 & \\
\hline MFLOLB & & & .855 & & & \\
\hline MFLISK & & & -.748 & & .338 & \\
\hline MFE20V & & & & .820 & & \\
\hline MBAP10 & & & & & -.796 & \\
\hline MFEBRL & & & & & & .836 \\
\hline MFEBML & & .420 & & & .315 & .583 \\
\hline MFLPRK & & & .311 & .355 & -.301 & .576 \\
\hline MFESDM & .436 & & & -.446 & & .452 \\
\hline
\end{tabular}

Key: MAGONT - agility on the ground; MAGKUS - side steps; MBFTAP - hand tapping; MBFTAN - foot tapping; MRCDTT - weight sit-ups; MRABPT - flat bench press; MSCHIL - a horizontal backrest; MRLPCT - half squats; MFLOLB - side laying leg raise; MFLISK - shoulder pass-throughs; MFE20V - a 20 m standing-start sprint; MBAP1O - onelegged stance on the balance platform; MFEBRL - seated handball throw (legs spread); MFEBML - lying medicine ball throw; MFLPRK - pike stretch (on a bench); MFESDM - standing long jump. 
Table 6. Matrix of interrelations among isolated latent dimensions

\begin{tabular}{ccccccc}
\hline Factors & 1 & 2 & 3 & 4 & 5 & 6 \\
\hline 1 & 1.000 & -.028 & .129 & -.059 & .006 & .154 \\
\hline 2 & -.028 & 1.000 & -.042 & .051 & .010 & .202 \\
\hline 3 & .129 & -.042 & 1.000 & .032 & -.084 & .064 \\
\hline 4 & -.059 & .051 & .032 & 1.000 & -.013 & -.018 \\
\hline 5 & .006 & .010 & -.084 & -.013 & 1.000 & -.096 \\
\hline 6 & .154 & .202 & .064 & -.018 & -.096 & 1.000 \\
\hline
\end{tabular}

\section{DISCUSSION}

The comparison of these results (as shown in Table 1) with the results obtained from the research conducted by Metohos, Hofman, Prot, Pintar, and Oreb (1989) on the population of the students at the Faculty of Physical Culture in Zagreb, in 1981, indicated no significant differences in the variables used to assess coordination (MAGONT and MAGKUS) and the variables used to assess explosive power of the upper extremities (MFEBML). The analysis of the results obtained demonstrate that the students at the Faculty of Physical Education have achieved better results in the variables used to assess the strength of the trunk MRCDTT and legs (MRLPCT), and the variables used to assess balance (MBAP1O) and the mobility of the shoulder joint (MFLISK), while the students at the Faculty of Security Sciences achieved better results in the variables used to assess the frequency of hand and leg movement (MBFTAN and MBFTAP), the explosive power of the lower and upper extremities (MFESDM, MFE20V and MFEBRL), the strength of arms, shoulders, and the back (MRABPT and MSCHIL), along with the variables used to assess the flexibility of the legs and arms (MFLOLB and MFLPRK). Based on the above results, we may conclude that the students at the Faculty of Physical Education have more strength in the trunk and legs and better mobility of the shoulder joint and balance than the students at the Faculty of Security Sciences, while the students at the Faculty of Security Sciences have a better frequency of movement by hand and leg, the explosive power of the lower and upper extremities, the repetitive strength of the arms and the static strength of the trunk, therefore a better flexibility of the trunk and legs. Given that the variability and co-variability of the tests for the frequency of movement is responsible for the ability to structure movement, while the explosive power is determined by the mechanism for regulating the excitation intensity and the repetitive and static forces of the mechanism for regulating the duration of excitation, we may consider these mechanisms to be at a higher level among the students at the Faculty of Security Sciences than among the students at the Faculty of Physical Culture.

The analysis of the inter-correlation matrix of the variables used to assess motor skills (Table 2) demonstrates that the most significant correlation was 
obtained within the set of variables used to assess coordination (MAGKUS and MAGONT). A significant correlation was also found within the set of variables used to assess repetitive power (MRCDTT and MRABPT) and (MRCDTT and MSCHIL), the set of variables used to assess explosive power (MFEBRL and MFEBML), followed by the set of variables used to assess explosive power and strength (MRLPCT and MRABPT), while a significant negative correlation was found within the set of variables used to assess flexibility (MFLOLB and MFLISK and MFLPRK and MFLISK). Also, a significant correlation was found between the variables used to assess flexibility and explosive power (MFLPRK and MFEBRL) and explosive power and strength (MFEBML and MRABPT), while a negative correlation was found between the variables used to assess coordination and explosive power (MAGONT and MFESDM). Given that the faster agility task performance (MAGONT) represents a better result, this correlation may be regarded as significant. A very weak (positive and negative) or insignificant correlation was found among other variables observed. Based on the value of the Kaiser-Meyer-Olkin indicator and the statistical significance of Bartlett's sphericity test, the model of factor analysis was used to determine the latent structure of the motor skills of the students at the Faculty of Security Sciences in Banja Luka.

By analyzing the main components (Table 3) using the Kaiser-Guttman rule, 6 significant latent dimensions were extracted, explaining a total of $63.93 \%$ of the variance of the entire system, whereby their individual contribution to the first principal component amounts to $17.095 \%$; $14.21 \%$ to the second one; $10.52 \%$ to the third one; $8.46 \%$ to the fourth one; $6.99 \%$ to the fifth one, and $6.64 \%$ to the sixth component of the common variance.

In considering the structure and the motor skills matrices (Table 4 and Table 5), it is obvious that the first isolated factor is clearly presented and composed of the variables used to assess coordination (MAGONT and MAGKUS) and the variables used to assess the frequency of movement (MBFTAP and MBFTAN), enabling the students to perform complex motor activities and appropriately reorganize them in new conditions. The ability to quickly change the direction of movement (based on the synchronization of the work of motor units) enables the rapid change of stances and guards, directions and attack directions, the rapid performance of combinations of strokes and blocks, defense moves and simultaneous movements, blocks and strokes during different attacks, while the frequency of movement is important in the realization of cyclical structures of attacks in those situations in which, for the purpose of attack or defense, a certain number of technical elements

76 such as movements combined with blocks, strokes, sweeps or throws (Milošević et al., 2005) is repeated. Considering the ability to control the movements of the whole body or certain parts of it in the space, and the speed of solving and performing complex motor tasks and performing simple movements with as many repetitions per unit time as possible, which is the essential characteristic of the content of most of the tasks of these measuring instruments (whose basis 
is best defined by the mechanism for structuring movements), this factor may be defined as a factor for structuring the movement.

The second isolated factor consists of the measures used to assess the repetitive and static strength of the arms, trunk, and legs (MRCDTT, MBABPT, MSCIL and MRLPCT), which is defined as the ability to perform long-term work on the basis of alternating contractions and muscle relaxations, as well as the ability to perform isometric contractions with certain duration, enabling the students to perform a number of activities and repetitions of certain techniques in education for the purpose of attacking or self-defense, including control over an opponent when carrying out transport on a shorter or longer journey. In defining a mechanism that would be responsible for repetitive and static power, we have taken into account the finding that the quantitative and qualitative characteristics of power depend on the anatomical, biomechanical and physiological characteristics of the locomotor apparatus as the subsystem being managed and the physiological and psychological characteristics of the central nervous system as the controlling subsystem underlain by physiological processes regulating the duration of excitation in those parts of the central nervous system that cause muscle activation; this factor may, therefore, be defined as the factor for the regulation of the duration of excitation.

The third factor has a very simple structure and is defined by the variables used to assess the flexibility measures (MFLOLB and MBFLISK), which is responsible for movement tasks requiring the ability to realize onetime maximum amplitude of movement, with the possibility of developing considerable excitation in the primary motor centers of the brain cortex and in those subcortical nuclei functioning as the amplifiers or modulators of eruptive information. Since the results of these tests are affected by the timely inclusion and exclusion of agonistic and antagonistic muscle groups as well as the fine regulation of the movement by which it is possible to describe the optimal path of movement (whose basis is best defined by the mechanism for tonus regulation and synergistic regulation), this factor may be defined as the factor for tone regulation and synergistic regulation.

The fourth factor is defined by the variable used to test explosive power through the run speed capability (MFE20V). Bearing in mind the fact that the speed of generating force determines the efficiency of the realization of blocks, strokes, and movement in the guard, and that the change in the speed of the force generation allows for a rapid detachment from the direction of attack, walking into the opponent, the rapid change of movement direction and sudden attack requiring discontinuous muscle strain (underlain by the excitation intensity of the neuromuscular system, which causes the excitation of the maximum possible number of motor units in performed or attempted motor movements), for which the mechanism for registration of excitation intensity is responsible, this factor may be defined as a factor of excitation intensity.

The fifth factor is determined by the variable used to assess balance (MBAP10) which is defined as the ability to maintain the balance position with 
open eyes in a given position on a reduced and stable surface of the support (both based on the information from the visual analyzer regarding body position in relation to the reference point and the information from the kinesthetic analyzer and vestibular apparatus), with random movements occurring as a noise generator. Bearing in mind the fact that the SPE content knowledge technique is a system of rational movements and movements manifested in the level of adoption achieved (such as typified movements, blocks, strokes, throws, sweeps and levers), whereby some body segments change their position (thereby disrupting balance), it follows that during a mutual attack, a student who knows how to maintain his or her own balance is more successful, while at the same time disrupting the opponent's balance, using his or her mistakes in the performance of certain attacks or interventions. Based on the finding that the manifestation of tone regulation in motor reactions controls the order, the ratio and the intensity of the inclusion and exclusion of the motor units of agonistic and antagonistic muscle groups, and the extent of force generated by this factor, this factor can be defined as a factor of synergistic regulation and tone regulation.

The sixth factor is represented by three explosive power measures (MFEBRL, MFEBML, MFESDM), which are part of the mechanism for assessing the regulation of excitation intensity (which is responsible for simultaneously activating the maximum number of units per unit time) and by one measure of flexibility (MFLPRK) in which the results depend to a large extent on the ability to regulate the tone of antagonists of the rear side of femur (which enables the maximum amplitude of the movement to be achieved), for which the mechanism for tone regulation and synergistic regulation is largely responsible. Given that the first two tests in their reactions include the musculature of the arm and shoulder area, and that the force produced is transmitted to the external objects which, under the effect of the force, move in space, while the third test includes the muscularity of the legs, whereby the force produced results in the displacement of the body in space, as well as the fact that the explosive power affects the speed of strokes, blocks, throws, walking into throws, defense against grips, defense against throws, breaking the opponent's guard followed by the speed of walking into the opponent in various attack types, to avoid attacks, the speed of defense against strokes, grips (Milošević et al., 2005), while the flexibility of the trunk influences the efficiency of the implementation of throw and lever techniques carried out with the body leaning forward as well as the throwing technique carried out with the body leaning backward, as well as the fact that the variable MFEBRL (underlain by short-term muscular contraction caused by the maximum amount of excitation of the central nervous system, for which the mechanism for regulating the excitation intensity is largely responsible) has the largest projection on this factor, it is possible to define this factor as a factor for excitation intensity.

Similar results were obtained by Shakiri, Lolić, Ademi, Saiti, and Kostovski (2013), who carried out research in a sample of 80 respondents to determine the structure of the basic-motor status of cadet judokas. Using 
factor analysis, they determined 6 factors defining the structure of the basic motor space and defined them as follows: 1) the factor for the mechanism of synergistic regulation and tone regulation; 2) the factor for the regulation of excitation duration and movement structure; 3) the factor for regulation and excitation intensity; 4) the factor for regulation, excitation duration, and movement structure; 5) the factor for synergistic regulation and tonus regulation (represented by balance measures), while they were unable to define the sixth factor due to the complexity of the character.

The analysis of the inter-correlation matrix of the isolated main components (Table 6) indicates a statistically significant weak correlation between the mechanism for regulating the duration of excitation (presented on the basis of the measures used to assess the repetitive and static forces) and the mechanism for the regulation of excitation intensity (presented on the basis of the measures used to assess explosive power). This is also supported by the conclusion that these two mechanisms together form a general factor that Gredelj et al. (1975) call the mechanism of energy regulation (whereby the action of the first regulation mechanism is manifested in the amount of motor work or the duration of muscle strain, while the other regulation mechanism is responsible for the magnitude of the forces developed per unit time). There was no statistically significant correlation between other factors. Likewise, the above facts are supported by the results of the study conducted by Božić, Milošević, and Zulić (1990), and Blagojević et al. (1994), which indicated that the quality of the formation of the complexes of the basic and derived algorithms in structuring programs in special physical education depends on the quality of the perception of longitudinal dimensionality and motor educability, with the information processes dominating in the first and second stage, while a more intense dynamic structure of motor programs occurs in the third stage, in which the contractile properties of the muscles come to the fore, as evidenced by the impact of the dynamic power of the upper extremity and trunk.

\section{CONCLUSION}

This study was conducted in a sample of 84 respondents to determine the structure of the basic-motor status among the students at the Faculty of Security Sciences in Banja Luka. Six latent motor factors were determined using the factor analysis according to the Kaiser-Guttman rule. The first factor is defined as the factor for the mechanism for structuring movement. The second factor is defined as the factor for the regulation and excitation duration mechanism. The third factor is defined as the factor for the tone regulation and synergistic regulation mechanism. The fourth factor is defined as the factor for the excitation intensity mechanism. The fifth factor is defined as the factor for synergistic regulation and tonus regulation, while the sixth factor is defined as the factor for excitation intensity. 
Based on the results of the factor analysis performed on the motor space, the model of motor skills among the students at the Faculty of Security Sciences may be defined as

$$
M=0.17 \mathrm{~F} 1+0.14 \mathrm{~F} 2+0.10 \mathrm{~F} 3+0.08 \mathrm{~F} 4+0.07 \mathrm{~F} 5+0.06 \mathrm{~F} 6
$$

where $M$ represents the model of motor characteristics, F1 - the factor for the movement structuring mechanism (presented on the basis of the measures used to assess coordination and the frequency of movements), F2 - the factor for the mechanism for regulating excitation duration (presented on the basis of the measures used to assess repetitive and static forces), F3 - the factor for the mechanism for tone regulation and synergistic regulation (presented on the basis of the measures used to assess flexibility), F4 - the factor for the excitation intensity mechanism (presented on the basis of the measures used to assess explosive power through the run speed capability), F5 - the factor for the synergistic regulation and tone regulation mechanism (presented on the basis of the measures used to assess balance), and F6 - the factor for the excitation intensity mechanism (presented on the basis of the measures used to assess explosive power).

Considering that future security personnel are likely to perform hazardous and complex tasks, it is very important that they have the optimum skills that could contribute to the successful performance of professional tasks. Due to the importance of motor skills within the system of selection, training, education and control of their level, there is a need for the continuous development and improvement of training programs and ways to determine the level of the general and specific motor skills achieved in order to improve the work ability of police officers and personnel employed at other security agencies (Anderson, Plecas \& Segger 2001; Dopsay and Vuckovic, 2006; Dopsay, Blagojevic and Vuckovic, 2007; Strating, et al., 2010; Vuckovic, Blagojevic and Dopsay, 2011). Given the above, in addition to learning and mastering the basic elements of techniques and their connections envisaged under the content knowledge of the SPE program, substantial attention should be given to the teaching process and a focus should be placed on the selection and formation of the model characteristics of each individual in order for future security personnel to be successful in their profession. Our research results open up possibilities for further research, and in combination with other test batteries, which may contribute to the selection of better candidates and improvement of the quality of the teaching process, thus producing more quality security personnel. 


\section{REFERENCES}

Anderson, S.G., Plecas, D., \& Segger, T. (2001). Police officer physical ability testing. Revalidating a selection criterion. Policing: An International Journal of Police Strategies \& Management, 24(1), 8-31.

Благојевић, М., ћирковић, З., Милошевић, М., Стојичић, Р., Јовановић, С., Арлов, Д., \& Допсај, М. (1994), Утицај неких адаптационих карактеристика приправника милиционара на ефекте учења моторичких алгоритама и програма у Специјалном физичком образовању, Зборник радова првог савјетовања из Специјалног физичког образовања Полицијске академије у Београду, $49-56$.

Благојевић, М. (1996). Утицај морфолошких и моторичких карактеристика полицајаца на ефикасност учења џудо техника, Полицијска академија Београд, Београд.

Благојевић, М., Допсај, М., \& Вучковцић, Г. (2006), Специјално физичко образовање 1 за студенте Полицијске академије , Инпресс- Београд, Београд.

Божић, С. Милошевић, М., \& Зулић, М. (1990). Утицај неких антрополошких карактеристика радника на структурирање моторичких алгоритама у Специјалном физичком образовању. Београд. 13. Мај, (2), 128 - 135.

Вучковић, Г. (2002). Утицај моторичких способности на ефикасност савладавања ситуационог пиштољског полигона код студената Полицијске академије. Магистарска теза, Београд. Факултет спорта и физичког васпитања Универзитета у Београду.

Вучковић, Г., Благојевић, М. \& Допсај, М. (2011). Специјално физичко образовање 2. Београд: Криминалистичко-полицијска академија.

Гредељ, М., Метикош, Д., Хошек, А. \& Момировић, К. (1975). Модел хијерархијске структуре моторичких способности, 1. резултати добијени примјеном једног неокласичног поступка за процјену латентних димензија. Кинезиологија, 5(1-2), 7-81.

Допсај, М., Милошевић, М., Благојевић, М., \& Вучковић, Г. (2002). Евалуација ваљаности тестова за процену контрактилног потенцијала мишића руку код полицајаца. Безбедност, 44(3), 434-444.

Допсај, М. \& Вучковић, Г. (2006). Показатељи максималне силе прегибача леве и десне шаке у функцији селекционог критеријума за потребе полиције. Спорт Монт, 4(10-11), 148-154.

Допсај, М; Благојевић, М, \& Вучковић, Г. (2007). Нормативно-селекциони критеријум за процену базично моторичког статуса кандидата за пријем на студије Криминалистичко-полицијске академије у Београду, Безбедност, 49(4), 166-183. 
Ђорђевић, Д. (1989). Опита антропомоторика. Београд. Факултет за физичку културу Универзитета у Београду.

Зациорски (1975). Физичка својства спортисте. Савез за физичку културу Југославије. Београд, 1975.

Јанковић, Р. \& Димитријевић, Р. (2012). Стање и могућности унапређења начина процене моторичких способности у систему Министарства унутрашњих послова Републике Србије, Култура полиса, 9(1)

Кукољ, М. (1996). Опита антропомоторика. Београд. Факултет за физичку културу Универзитета у Београду.

Курелић, Н., Момировић, К., Стојановић, М., Штурм, Ј., Радојевић, Ђ. \& ВискићШталец, Н. (1975). Структура и развој морфолошких и моторичких димензија омладине. Институт за научна истраживања Факултета за физичко васпитање. Београд.

Метикош Д,. Хофман Е,. Прот Ф,. Пинтар Ж. \& Ореб Г. (1989). Мјерење базичних моторичких димензија спорташа, Факултет за Физичку културу, Загреб.

Милошевић, М. (1985). Одређивање структуре моторичких својстава милиционара, ВШУП. Београд,

Милошевић, М., Гавриловић, П. \& Иванчевић, Б. (1988). Моделирање и управљање системом самоодбране. Научна књига: Београд.

Милошевић,М. \& Зулић, М. (1988). Утицај неких димензија снаге на ефикасност гађања из пиштоља.13.мај,41 (2), 89 - 92.

Милошевић, М., Мудрић, Р., Јовановић, С., Амановић, Ћ. \& Допсај, М. (2005). Конституисање система за управљање тренутним и кумулативним едукативним и тренажним ефектима у СФО-у. Монографија из истраживачког пројекта «Полиција у функцији безбједности и заштите у Србији на почетку XXI века“. ВШУП. Београд.

Strating, M., Bakker, R., Dijkstra, G., Lemmink, K., \& Groothoff, J.W. (2010). A jobrelated fitness test for the Dutch police. Occupational Medicine, 60, 255-260.

Схакири, К., Лолић, Д., Адеми, А., Саити, Б. \& Костовски, Ж. (2013). Структура варијабли за процјену базично-моторичких димензија код младих џудиста. Зборник радова са петог међународног конгреса „Антрополошки аспекти спорта, физичког васпитања и рекреације“"Вол. (5) 144 - 150. Факултет физичког васпитања и спорта Универзитета у Бањој Луци.

Paper received on: 03. 12. 2018.

Paper accepted for publishing on: 29. 03. 2019. 


\title{
СТРУКТУРА МОТОРИЧКИХ СПОСОБНОСТИ СТУДЕНАТА ФАКУЛТЕТА БЕЗБЈЕДНОСНИХ НАУКА
}

\begin{tabular}{|l|l|l|}
\hline DOI 10.7251/ZBK1901071P & COBISS.RS-ID 8273432 & УДК 572.512-057.875 \\
\hline
\end{tabular}

\section{Оригинални научни рад}

\author{
Дарко Паспаљ ${ }^{1}$ \\ Факултет безбједносних наука, Универзитет у Бањој Луци \\ Милан Гужвица \\ Факултет безбједносних наука, Универзитет у Бањој Луци \\ Лазар Вулин \\ Основна школа Козице, Оштра Лука
}

Апстракт: На узорку од 84 студента Факултета безбједносних наука из Бањалуке, примијењен је систем од 16 моторичких варијабли с циљем да се утврди структура њихових моторичких способности. Примјеном факторске анализе по Кајзер-Гутмановом критеријуму утврђено је 6 латентних моторичких димензија. Први фактор дефинисан је као фактор механизма за структурирање кретања, јер је представљен варијаблама за процјену координације и фреквенције покрета. Други фактор дефинисан је као фактор механизма за регулацију трајања ексцитације, јер је представљен мјерама за процјену репетитивне и статичке снаге руку, трупа и ногу. Трећи фактор дефинисан је као фактор механизма за регулацију тонуса и синергијску регулацију, јер је представљен варијаблама за процјену мјера флексибилности. Четврти фактор дефинисан је као фактор механизма интензитета ексцитације, јер је представљен варијаблом којом се испитује експлозивна снага кроз способност брзине трчања. Пети фактор је такође дефинисан као фактор синергијске регулације и регулације тонуса, јер је престављен варијаблом за процјену равнотеже, док је шести фактор дефинисан као фактор интензитета ексцитације, јер је представљен са три варијабле за процјену експлозивне снаге и једном варијаблом за процјену флексибилности. Овај рад је покушај да се покаже да је издвојена хијерархијска структура моторичких способности од изузетне теоријске и практичне вриједности, при чему би поменути фактори требали представљати одредницу за предикцију моторичких способности и програмирање тренажних оператора у настави Специјалног физичког образовања.

Кључне ријечи: факторска анализа, студенти, моторичке способности

\footnotetext{
${ }^{1}$ Аутор за кореспонденцију: др Дарко Паспаљ, доцент на Факултету безбједносних наука, Универзитет у Бањој Луци. E-mail:darko.paspalj@fbn.unibl.org
} 


\section{УВОД}

Процеси избора, усмјеравања и праћења у области специјалног физичког образовања, незамисливи су без информација о моторичким способностима студената, из чега произлази да је за озбиљно програмирање кинезиолошких тренажних оператора неопходно познавање структуре моторичких способности, које су одговорне за ефикасност моторичког понашања студената Факултета безбједносних наука код рјешавања ситуационо-моторичких проблема различитог нивоа сложености у концептуалним и ситуационим условима. Под моторичким способностима најчешће се подразумијевају својства индивидуе која изражавају његову физичку припремљеност за извођење одређеног рада и способност за стваралачко испољавање властите личности а које се у експерименталним истраживањима обично своде на операционално дефинисане латентне димензије изведене из неког система мјерних инструмената. Досадашња истраживања хијерархијског функционалног модела моторичких способности (Зациорски, 1975; Гредељ, Метикош, Хошек \& Момировић, 1975; Ђорђевић, 1989; Кукољ 1996) указују на то да су у простору првог реда дефинисани хипотетски фактори феноменолошког модела који обухватају координацију, снагу, издржљивост, брзину, флексибилност, прецизност и равнотежу, док су на основу истраживања Курелића и сарадника (1975), са аспекта функционалних механизама у простору другог реда дефинисани хипотетски фактори који обухватају: механизам за структурирање кретања, механизам за регулацију тонуса и синергијску регулацију, механизам за регулацију интензитета ексцитације и механизам за регулацију трајања ексцитације. Специјално физичко образовање (СФО) као дио физичке културе има за циљ психосоматско усавршавање студената кроз постизање и одржавање базичних и специјалних знања и способоности (Благојевић, Допсај \& Вучковцић, 2006), при чему добро дефинисан едукативни и тренажни третман, треба да трансформише опште и специјалне физичке способности у складу са професионалним потребама радника МУП-а и других агенција које се баве безбједносним пословима (Милошевић, 1985; Милошевић \& Зулић, 1988; Милошевић, Гавриловић \& Иванчевић, 1988; Благојевић, Допсај \& Вучковић, 1996; Вучковић, 2002; Допсај, Милошевић, Благојевић \& Вучковић, 2002). Програмске активности СФО-а, спадају у полиструктуралне ацикличке активности које карактерише мноштво техничких елемената, богата тактика поступања, разноликост покрета цијелог тијела и појединих његових дијелова у различитим правцима са промјењивом јачином и темпом дјеловања при чему моторичке способности имају доминантну улогу у односу на остале адаптивне карактеристике (Милошевић, Мудрић, Јовановић, Амановић \& Допсај, 2005). Имајући у виду наведено можемо закључити да су добро развијене моторичке способности и адекватан ниво увјежбаности специфичних моторичких задатака један од основних фактора којима се обезбјеђују услови за успјешност у раду радника МУП-а и других агенција које се баве безбједносним пословима (Милошевић, 1985; Благојевић и сарадници, 2006; Допсај и сарадни- 
ци 2002). С обзиром на то да сазнање о смјеру и интензитету дјеловања на трансформацију психосоматског статуса студената омогућује адекватно и оптимално програмирање наставних садржаја СФО-а, а да је на основу досад објављених истраживања, утврђено да моторичке способности у великој мјери утичу на ефиканост усвајања и примјену програмских садржаја СФО-а, као и чињеницу да настава СФО-а значајно утиче на трансформацију моторичких способности студената, ово истраживање је имало за циљ утврђивање моторичке хијерархијске структуре код студената Факултета безбједносних наука у Бањалуци, ради класифицирања студената на основу моторичких способности у што хомогеније групе, због боље ефикасности извођења наставе из наставног предмета специјално физичко образовање. На основу овако дефинисаног циља истраживања као и чињенице да се ради о позитивно селекционисном узорку претпоставка је да студенти Факултета безбједносних наука имају одговарајућу структуру моторичких способности, те да ће алгоритам факторске анализе трансформисати скуп манифестних моторичких варијабли у предвиђен број релевантних моторичких фактора.

\section{МЕТОДЕ ИСТРАЖИВАҢА}

\section{Узорак исиийиника}

Узорак испитаника сачињавала су 84 студента мушког пола, прве године Факултета безбједносних наука из Бањалуке, старосне доби $19 \pm$ 0,6 година. Сви ентитети који су сачињавали узорак били су клинички здрави и без видљивих морфолошких недостатака. Основни антропоморфолошки

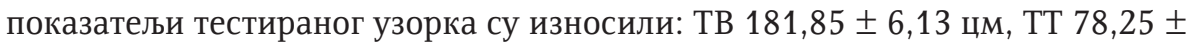

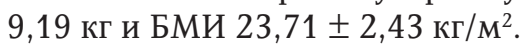

\section{Узорак варијабли}

Овим истраживањем није било могуће обухватити цијели простор моторике, због тога је извршен покушај да се анализа структуре моторичких способности врши на нивоу фактора другог реда са репрезентативним мјерним инструментима за процјену примарних фактора, при чему је простор моторике био покривен са 16 тестова: тапинг руком (МБФТАП), тапинг ногом (МБФТАН), окретност на тлу (МАГОНТ), кораци у страну (МАГКУС), стајање на једној нози попречно на клупици за равнотежу (МБАП10), искрет (МФЛИСК), одножење лежећи бочно (МФЛОЛБ), претклон на клупи (МФЛПРК), скок у даљ с мјеста (МФЕСДМ), спринт из високог старта на 20 м (МФЕ20В), бацање медицинке из лежања на леђима (МФЕБМЛ), бацање рукометне лопте из сједа разножног са тла (МФЕБРЛ), потисак са равне клупе (МРАБПТ), подизање трупа с теретом (МРЦДТТ), получучњеви с теретом (МРЛПЦТ) и хоризонтални издржај на леђима (МСЦХИЛ). Све варијабле за процјену моторичких способности посједују потребне метријске карактеристике (Метикош и сарадници 1989). 


\section{МЕТОДЕ ОБРАДЕ ПОДАТАКА}

Статистичка обрада података урађена је на ПЦ рачунару Пентијум IV, уз употребу апликационог статистичког програма СПСС (верзија 20,00). Основне мјере централне тенденције и мјере дисперзије резултата дефинисане су помоћу: аритметичке средине и стандардне девијације. У циљу тестирања правилности дистрибуције података коришћен је Колмогоров-Смирнов тест, док је тестирање алтернативне хипотезе извршено примјеном мултиваријантног модела факторске анализе, гдје је значајност главних компоненти утвђена на основу Кајзер-Гутмановог критеријума. Да би се утврдиле стварне релације међу издвојеним димензијама користила се Облимин ротација, након чега је добијена матрица структуре и матрица склопа.

\section{РЕЗУЛТАТИ}

У Табели 1 приказани су дескриптивни параметри варијабли за процјену моторичких способности. Повећане вриједности стандардне девијације мјера за процјену флексибилности, експлозивне снаге и снаге упућују на велику варијабилност резултата око аритметичких средина али узимајући у обзир величину узорка ову појаву можемо сматрати нормалном. Резултати Колмогоров-Смирнов теста за анализу нормалности распореда показују да већина варијабли описује нормалан распоред, док су вриједности мање од 0,05 забиљежене код варијабли за процјену координације и равнотеже (МАГОНТ, МАГКУС и МБАП1О), као и код варијабли за процјену флексибилности и снаге (МБФЛОЛБ и МРЛЦДТТ).

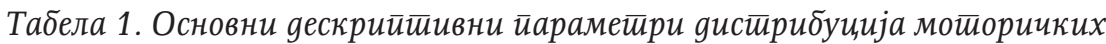
варијабли

\begin{tabular}{ccccc}
\hline Варијабле & Број испитаника $\begin{array}{c}\text { Средња } \\
\text { виједност }\end{array}$ & $\begin{array}{c}\text { Стандардно } \\
\text { одступање }\end{array}$ & $\begin{array}{c}\text { Колмогоров- } \\
\text { Смирнов тест } \\
\text { (значајност) }\end{array}$ \\
\hline МБФТАП & 84 & 40.49 & 6.35 & 0.054 \\
\hline МБФТАН & 84 & 32.45 & 3.90 & 0.054 \\
\hline МАГОНТ & 84 & 12.87 & 3.70 & 0.002 \\
\hline МАГКУС & 84 & 9.24 & 1.40 & 0.021 \\
\hline МБАП1О & 84 & 3.71 & 2.96 & 0.002 \\
\hline МФЛИСК & 84 & 75.18 & 19.27 & 0.096 \\
\hline МФЛОЛБ & 84 & 72.29 & 11.33 & 0.043 \\
\hline МФЛПРК & 84 & 50.73 & 9.38 & 0.140 \\
\hline МФЕСДМ & 84 & 248.73 & 15.16 & 0.844 \\
\hline МФЕ20В & 84 & 3.31 & 0.14 & 0.727 \\
\hline МФЕБМЛ & 84 & 130.00 & 18.19 & 0.224 \\
\hline МФЕБРЛ & 84 & 190.00 & 32.71 & 0.677 \\
\hline
\end{tabular}




\begin{tabular}{ccccc}
\hline Варијабле & Број испитаника $\begin{array}{c}\text { Средња } \\
\text { вриједност }\end{array}$ & $\begin{array}{c}\text { Стандардно } \\
\text { одступање }\end{array}$ & $\begin{array}{c}\text { Колмогоров- } \\
\text { Смирнов тест } \\
\text { (значајност) }\end{array}$ \\
\hline МРАБПТ & 84 & 34.98 & 11.95 & 0.173 \\
\hline МРЦДТТ & 84 & 26.77 & 9.71 & 0.034 \\
\hline МРЛПЦТ & 84 & 23.49 & 9.06 & 0.082 \\
\hline МСЦХИЛ & 84 & 23.46 & 10.86 & 0.062 \\
\hline Н & 84 & & & \\
\hline
\end{tabular}

Легенда: Н - број испитаника; Меан - аритметичка средина; Стд. Девиатион стандардна девијација; КСп - вриједност вјероватноће Колмогоров-Смирнов теста; МБФТАП - тапинг руком; МБФТАН - тапинг ногом; МАГОНТ - окретност на тлу; МАГКУС - кораци у страну; МБАП1О - стајање на једној нози попречно на клупици за равнотежу; МФЛИСК - искрет; МФЛОЛБ - одножење лежећи бочно; МФЛПРК - претклон на клупи; МФЕСДМ - скок у даљ с мјеста; МФЕ20В - спринт из високог старта на 20 м; МФЕБМЛ - бацање медицинке из лежања на леђима; МФЕБРЛ - бацање рукометне лопте из сједа разножног са тла; МРАБПТ - потисак са равне клупе; МРЦДТТ - подизање трупа с теретом; МРЛПЦТ - получучњеви с теретом; МСЦХИЛ - хоризонтални издржај на леђима,

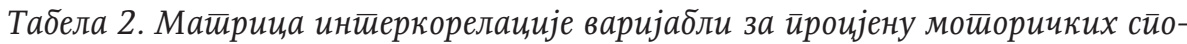
собности $u$

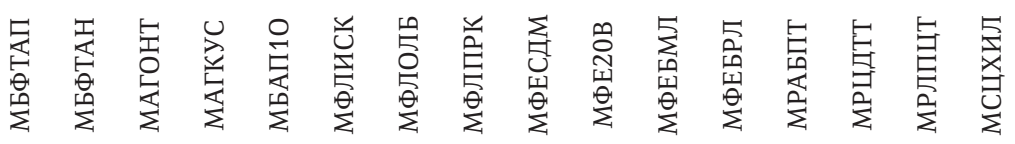

\begin{tabular}{|c|c|}
\hline МБФТАП & 1.00 \\
\hline МБФТАН & .2131 .00 \\
\hline МАГОНТ & $-.277-.2541 .00$ \\
\hline МАГКУС & $-.289-.244 .6171 .00$ \\
\hline МБАП10 & $.022 .011-.132-.1461 .00$ \\
\hline МФЛИСК & $-.074-.089-.029 .009-.1941 .00$ \\
\hline МФЛОЛБ & $\begin{array}{llll}.145 .010 & -.097-.009-.4351 .00 \\
\end{array}$ \\
\hline МФЛПРК & $.072-.013-.118-.173 .113-.357 .1521 .00$ \\
\hline МФЕСДМ & $.164 .157-.318-.235 .200-.038 .099 .1421 .00$ \\
\hline МФЕ20B & $.089-.042-.006-.030-.077-.087 .083 .082-.1811 .00$ \\
\hline МФЕБМЛ & $.060-.072-.131-.049-.174 .024-.095 .131 .178-.0731 .00$ \\
\hline МФЕБРЛ & . $169-.088-.101-.268 .104-.100 .068 .351 .281-.102 .3261 .00$ \\
\hline МРАБПТ & 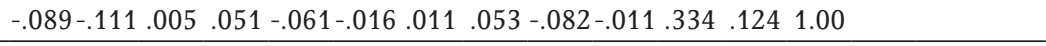 \\
\hline МРЦДТТ & $.114-.180-.017-.038-.124 .082 .061 .202-.046-.060 .253 .099 .454 \quad 1.00$ \\
\hline МРЛПЦТ & 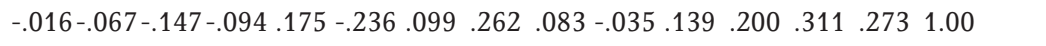 \\
\hline МСЦХИЛ & 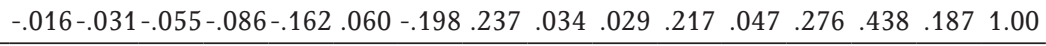 \\
\hline
\end{tabular}


Легенда: МБФТАП - тапинг руком; МБФТАН - тапинг ногом; МАГОНТ - окретност на тлу; МАГКУС - кораци у страну; МБАП1О - стајање на једној нози попречно на клупици за равнотежу; МФЛИСК - искрет; МФЛОЛБ - одножење лежећи бочно; МФЛПРК - претклон на клупи; МФЕСДМ - скок у даљ с мјеста; МФЕ20В - спринт из високог старта на 20 м; МФЕБМЛ - бацање медицинке из лежања на леђима; МФЕБРЛ - бацање рукометне лопте из сједа разножног са тла; МРАБПТ - потисак са равне клупе; МРЦДТТ - подизање трупа с теретом; МРЛПЦТ - получучњеви с теретом; мСЦХИЛ - хоризонтални издржај на леђима,

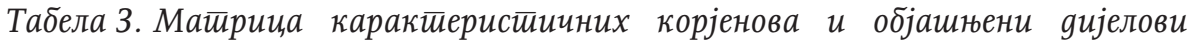
зајеgничке варијансе

\begin{tabular}{|c|c|c|c|c|c|c|c|}
\hline \multirow{2}{*}{$\begin{array}{c}\text { Компо- } \\
\text { ненте }\end{array}$} & \multicolumn{3}{|c|}{ Почетне својствене вриједности } & \multicolumn{3}{|c|}{ Сума квадрата оптерећења } & \multirow{2}{*}{$\begin{array}{c}\text { Ротација } \\
\text { суме } \\
\text { квадрата } \\
\text { Каракте- } \\
\text { ристични } \\
\text { коријен }\end{array}$} \\
\hline & $\begin{array}{c}\text { Каракте- } \\
\text { ристични } \\
\text { коријен }\end{array}$ & $\begin{array}{c}\text { Варијан- } \\
\text { са } \\
\%\end{array}$ & $\begin{array}{c}\text { Куму- } \\
\text { лативни } \\
\text { низ } \\
\%\end{array}$ & $\begin{array}{c}\text { Карак- } \\
\text { тери- } \\
\text { стични } \\
\text { коријен }\end{array}$ & $\begin{array}{c}\text { Ва- } \\
\text { ријанса } \\
\%\end{array}$ & $\begin{array}{c}\text { Куму- } \\
\text { лативни } \\
\text { низ } \\
\%\end{array}$ & \\
\hline 1 & 2.735 & 17.091 & 17.091 & 2.735 & 17.091 & 17.091 & 2.235 \\
\hline 2 & 2.275 & 14.216 & 31.307 & 2.275 & 14.216 & 31.307 & 2.249 \\
\hline 3 & 1.683 & 10.521 & 41.828 & 1.683 & 10.521 & 41.828 & 1.762 \\
\hline 4 & 1.355 & 8.469 & 50.297 & 1.355 & 8.469 & 50.297 & 1.233 \\
\hline 5 & 1.119 & 6.993 & 57.290 & 1.119 & 6.993 & 57.290 & 1.392 \\
\hline 6 & 1.063 & 6.643 & 63.933 & 1.063 & 6.643 & 63.933 & 1.921 \\
\hline 7 & .899 & 5.621 & 69.554 & & & & \\
\hline 8 & .834 & 5.211 & 74.765 & & & & \\
\hline 9 & .714 & 4.462 & 79.226 & & & & \\
\hline 10 & .662 & 4.140 & 83.366 & & & & \\
\hline 11 & .613 & 3.834 & 87.200 & & & & \\
\hline 12 & .571 & 3.570 & 90.770 & & & & \\
\hline 13 & .481 & 3.005 & 93.775 & & & & \\
\hline 14 & .423 & 2.643 & 96.419 & & & & \\
\hline 15 & .289 & 1.807 & 98.225 & & & & \\
\hline 16 & .284 & 1.775 & 100.000 & & & & \\
\hline
\end{tabular}




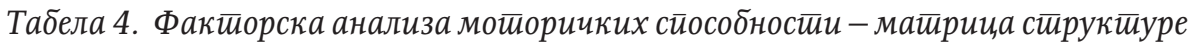

\begin{tabular}{|c|c|c|c|c|c|c|}
\hline \multicolumn{7}{|c|}{ Матрица структуре } \\
\hline & 1 & 2 & 3 & 4 & 5 & 6 \\
\hline МАГОНТ & -.845 & & & & & \\
\hline МАГКУС & -.811 & & & & & \\
\hline МБФТАН & .522 & & .382 & & & -.357 \\
\hline МБФТАП & .515 & & & & & \\
\hline МРЦДТТ & & .783 & & & & \\
\hline МРАБПТ & & .766 & & & & \\
\hline МСЦХИЛ & & .643 & & & & \\
\hline МРЛПЦТ & & .554 & & & -.494 & \\
\hline МФЛОЛБ & & & .870 & & & \\
\hline МФЛИСК & & & -.729 & & & \\
\hline МФЕ20B & & & & .829 & & \\
\hline МФЕСДМ & .340 & & & -.413 & & .410 \\
\hline МБАП10 & & & & & -.796 & \\
\hline МФЕБРЛ & & & & & & .839 \\
\hline МФЕБМЛ & & .311 & & & .356 & .557 \\
\hline МФЛПРК & & & & .350 & & .505 \\
\hline
\end{tabular}

Легенда: МАГОНТ - окретност на тлу; МАГКУС - кораци у страну; МБФТАН - тапинг ногом; МБФТАП - тапинг руком; МРЦДТТ - подизање трупа с теретом; МРАБПТ потисак са равне клупе; МСЦХИЛ - хоризонтални издржај на леђима; МРЛПЦТ получучњеви с теретом; МФЛОЛБ - одножење лежећи бочно; МФЛИСК - искрет; МФЕ20В - спринт из високог старта на 20 м; МФЕСДМ - скок у даљ с мјеста; МБАП10 - стајање на једној нози попречно на клупици за равнотежу; МФЕБРЛ - бацање рукометне лопте из сједа разножног са тла; МФЕБМЛ - бацање медицинке из лежања на леђима; МФЛПРК - претклон на клупи; 


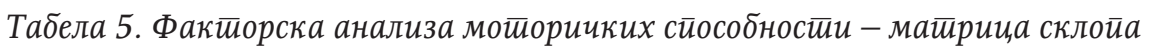

\begin{tabular}{|c|c|c|c|c|c|c|}
\hline \multicolumn{7}{|c|}{ Матрица склопа } \\
\hline & 1 & 2 & 3 & 4 & 5 & 6 \\
\hline МАГОНТ & -.820 & & & & & \\
\hline МАГКУС & -.807 & & & & & \\
\hline МБФТАП & .558 & & & & & \\
\hline МБФТАН & .533 & & .406 & & & \\
\hline МРЦДТТ & & .789 & & & & \\
\hline МРАБПТ & & .754 & & & & \\
\hline МСцХиЛ & & .661 & & & & \\
\hline МРЛПЦТ & & .546 & & & -.508 & \\
\hline МФлОль & & & .855 & & & \\
\hline МФЛИСК & & & -.748 & & .338 & \\
\hline МФЕ20В & & & & .820 & & \\
\hline МБАП10 & & & & & -.796 & \\
\hline МФЕБРЛ & & & & & & .836 \\
\hline МФЕБМЛ & & .420 & & & .315 & .583 \\
\hline МФЛПРК & & & .311 & .355 & -.301 & .576 \\
\hline МФЕСДМ & .436 & & & -.446 & & .452 \\
\hline
\end{tabular}

Легенда: МАГОНТ - окретност на тлу; МАГКУС - кораци у страну; МБФТАП - тапинг руком; МБФТАН - тапинг ногом; МРЦДТТ - подизање трупа с теретом; МРАБПТ - потисак са равне клупе; МСЦХИЛ - хоризонтални издржај на леђима; МРЛПЦТ - получучњеви с теретом; МФЛОЛБ - одножење лежећи бочно; МФЛИСК - искрет; МФЕ20В - спринт из високог старта на 20 м; МБАП10 - стајање на једној нози попречно на клупици за равнотежу; МФЕБРЛ - бацање рукометне лопте из сједа разножног са тла; МФЕБМЛ - бацање медицинке из лежања на леђима; МФЛПРК претклон на клупи; МФЕСДМ - скок у даљ с мјеста; 


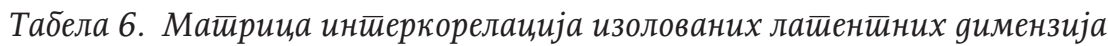

\begin{tabular}{ccccccc}
\hline Фактори & 1 & 2 & 3 & 4 & 5 & 6 \\
\hline 1 & 1.000 & -.028 & .129 & -.059 & .006 & .154 \\
\hline 2 & -.028 & 1.000 & -.042 & .051 & .010 & .202 \\
\hline 3 & .129 & -.042 & 1.000 & .032 & -.084 & .064 \\
\hline 4 & -.059 & .051 & .032 & 1.000 & -.013 & -.018 \\
\hline 5 & .006 & .010 & -.084 & -.013 & 1.000 & -.096 \\
\hline 6 & .154 & .202 & .064 & -.018 & -.096 & 1.000 \\
\hline
\end{tabular}

\section{ДИСКУСИЈА}

Поређењем резултата овог истраживања (приказаних у Табели 1) са резултатима истраживања које су према Метикош, Хофман, Прот, Пинтар и Ореб (1989) исти аутори провели 1981. године на популацији студената Факултета за физичку културу из Загреба, не уочавају се битне разлике код варијабли којима је процјењивана координација (МАГОНТ и МАГКУС) те варијабле за процјену експлозивне снаге горњих екстремитета (МФЕБМЛ). На основу увида у остварене резултате показало се да су студенти Факултета за физичку културу остварили боље резултате код варијабли за процјену снаге трупа (МРЦДТТ) и ногу (МРЛПЦТ), те варијабле за процјену равнотеже (МБАП10), као и варијабле за процјену покретљивости у зглобу рамена (МФЛИСК), док су студенти Факултета безбједносних наука остварили боље резултате код варијабли за процјену фреквенције покрета руком и ногом (МБФТАН и МБФТАП), те варијабли за процјену експлозивне снаге доњих и горњих екстремитета (МФЕСДМ, МФЕ20В и МФЕБРЛ) и снаге руку, раменог појаса и леђа (МРАБПТ и МСЦХИЛ), као и варијабли за процјену флексибилности ногу и трупа (МФЛОЛБ и МФЛПРК). На основу наведеног можемо закључити да студенти Факултета за физичку културу имају већу снагу трупа и ногу те бољу покретљивост у зглобу рамена и равнотежу од студената Факултета безбједносних наука, док студенти Факултета безбједносних наука имају бољу фреквенцију покрета руком и ногом, експлозивну снагу доњих и горњих екстремитета, репетитивну снагу руку и статичку снагу трупа те бољу флексибилност трупа и ногу. С обзиром на то да је варијабилитет и коваријабилитет тестова за фреквенцију покрета одговоран за способност структурирања кретања, док експлозивну снагу одређује механизам за регулацију интензитета екситације а репетитивну и статичку снагу механизам за регулацију трајања екситације, можемо сматрати да су ови механизми код студената Факултета безбједносних наука на вишем нивоу у односу на студенте Факултета за физичку културу.

Анализом матрице интеркорелација варијабли за процјену моторичких споцсобности (Табела 2) може се уочити да је највећа повезаност добије- 
на унутар блока варијабли за процјену координације (МАГКУС и МАГОНТ). Значајна повезаност забиљежена је и унутар блока варијабли за процјену репетитивне снаге (МРЦДТТ и МРАБПТ) и (МРЦДТТ и МСЦХИЛ), блока варијабли за процјену експлозивне снаге (МФЕБРЛ и МФЕБМЛ) и блока варијабли за процјену снаге (МРЛПЦТ и МРАБПТ), док је значајна негативна повезаност добијена унутар блока варијабли за процјену флексибилности (МФЛОЛБ и МФЛИСК и МФЛПРК и МФЛИСК). Такође, значајна повезаност забиљежена је и између варијабли за процјену флексибилности и експлозивне снаге (МФЛПРК и МФЕБРЛ), као и варијабли за процјену експлозивне снаге и снаге (МФЕБМЛ и МРАБПТ), док је негативна повезаност добијена између варијабли за процјену координације и експлозивне снаге (МАГОНТ и МФЕСДМ). С обзиром на то да остварено мање вријеме у тесту окретност на тлу (МАГОНТ) представља бољи резултат, ову повезаност можемо сматрати значајном. Између осталих посматраних варијабли добијена је веома слаба (позитивна и негативна) или безначајна повезаност. На основу вриједности Кајзер-Мејер-Оклиновог показатеља и статистичке значајности Бартлетовог теста сферичности, моделом факторске анализе утврђена је латентна стуктура моторичких способности студената Факултета безбједносних наука из Бањалуке.

Анализом главних компоненти (Табела 3) уз примјену Кајзер-Гутмановог критеријума екстраховано је 6 значајних латентних димензија које укупно објашњавају 63,93\% варијансе цијелог система, при чему њихов појединачни допринос износи за прву главну компоненту 17,09 5\%, за другу $14,21 \%$, за трећу $10,52 \%$, за четврту $8,46 \%$, за пету $6,99 \%$ и за шесту $6,64 \%$ заједничке варијансе.

На основу матрице структуре и матрице склопа моторичких способности (Табеле 4 и 5) видљиво је да први изоловани фактор јасно представљен и састављен од варијабли за процјену координације (МАГОНТ и МАГКУС) и варијабли за процјену фреквенције покрета (МБФТАП и МБФТАН), што омогућава студентима да врше сложене моторне радње и да их адекватно реорганизују у новим условима. Способност брзе промјене правца кретања (у чијој основи стоји синхронизација рада моторних јединица) омогућава брзу промјену ставова и гардова, брзу промјену смјера и правца напада, брзо извођење комбинација кретања са ударцима и блоковима, брзо извођење одбрана и истовремено извођење кретања, блокова и удараца при различитим нападима, док је фреквенција покрета битна у реализацији цикличких структура напада, у оним ситуацијама у којима се у циљу напада или одбране понавља одређени број техничких елемената као што су 78 кретања комбинована са блоковима, ударцима, чишћењима или бацањима (Милошевић и сарадници 2005). С обзиром на то да је ријеч о способности управљања покретима цијелог тијела или одређеним његовим дијеловима у простору, те да је брзина рјешавања и извођења комплексних моторичких задатака и извођење једноставних покрета уз што већи број понављања у јединици времена суштинско обиљежје садржине већине задатака ових мјер- 
них инструмената (чију основу најбоље дефинише механизам за структурирање кретања), овај фактор можемо дефинисати као фактор структурирања кретања.

Други изоловани фактор састоји се од мјера за процјену репетитивне и статичке снаге руку, трупа и ногу (МРЦДТТ, МБАБПТ, МСЦИЛ и МРЛПЦТ), која је дефинисана као способност дуготрајног рада на темељу наизмјеничних контракција и релаксација мишића и као способност извођења изометријских контракција са одређеним трајањем, што омогућава студентима велики број извођења и понављања одређених техника приликом едукације у циљу напада или одбране, као и контролу над противником приликом извођења транспорта на краћем или дужем путу. У дефинисању механизма који би био одговоран за репетитивну и статичку снагу пошло се од сазнања да квантитативне и квалитативне карактеристике снаге зависе о анатомским, биомеханичким и физиолошким карактеристикама локомоторног апарата као подсистема којим се управља и о физиолошким и психолошким карактеристикама централног нервног система као управљајућег подсистема у чијој основи физиолошких процеса је регулисање трајања ексцитације у оним дијеловима централног нервног система који изазивају активирање мишића, тако да овај фактор можемо дефинисати као фактор регулације трајања ексцитације.

Трећи фактор има врло једноставну структуру а дефинишу га варијабле за процјену мјера флексибилности (МФЛОЛБ и МБФЛИСК) у чијој основи су кретни задаци који захтијевају способност реализације једнократне максималне амплитуде покрета, са могућности развијања велике ексцитације у примарним моторичким центрима мождане коре и у оним субкортикалним језгрима који функционишу као амплификатори или модулатори еферентних информација. С обзиром на то да на резултате у овим тестовима утиче правовремено укључивање и искључивање агонистичких и антагонистичких мишићних група те фина регулација кретања којом је могуће описати оптималну путању кретања (чију основу најбоље дефинише механизам за регулацију тонуса и синергијску регулацију), тако да овај фактор можемо дефинисати као фактор за регулацију тонуса и синергијску регулацију.

Четврти фактор дефинише варијабла којом се испитује експлозивна снага кроз способност брзине трчања (МФЕ20В). Имајући у виду чињеницу да брзина генерисања силе условљава ефикасност реализације блокова, удараца и кретања у гарду, а да промјена брзине генерисања силе омогућава нагла склањања са правца напада, улажења у противника, брзу промјену смјера кретања и изненадне нападе што захтијева дисконтинуирано напрезање мишића (у чијој основи је интензитет ексцитације неуромишићног система који проузрокује ексцитацију максимално могућег броја моторних јединица при изведеним или покушаним моторичким покретима), за шта је одговоран механизам за регулацију интензитета ексцитације, овај фактор можемо дефинисати као фактор интензитета ексцитације. 
Пети фактор одређује варијабла за процјену равнотеже (МБАП10), дефинисана као способност одржавања равнотежног положаја отворених очију у заданом положају на смањеној и стабилној површини ослонца (како на основу информација из видног анализатора о положају тијела у поређењу са референтном тачком, тако и на основу информација из кинестетичког анализатора и вестибуларног апарата), при чему се као генератор шума јављају случајни покрети. Имајући у виду чињеницу да технику програмских садржаја СФО-а представља систем рационалних покрета и кретњи који се испољавају у достигнутим нивоима усвојености (као што су типизирана кретања, блокови, ударци, бацања, чишћења и полуге), којом приликом поједини сегменти тијела мијењају међусобни положај (па самим тим ремете и равнотежу), произлази да је током обостраног напада успјешнији онај студент који зна да одржава властиту равнотежу а да притом истовремено ремети противникову равнотежу и користи његове грешке при извођењу одређених напада или захвата. На основу сазнања да манифестација регулације тонуса у моторичким реакцијама контролише редослијед, омјер и интензитет укључивања и искључивања моторичких јединица агонистичких и антагонистичких мишићних скупина као и величину силе која се у њима генерише и овај фактор је могуће дефинисати као фактор синергијске регулације и регулације тонуса.

Шести фактор представљен је преко три мјере експлозивне снаге (МФЕБРЛ, МФЕБМЛ, МФЕСДМ) које се налазе у склопу механизма за процјену регулације интензитета екситације (који је одговоран за истовремено активирање максималног броја моторичких јединица у јединици времена) и једне мјере флексибилности (МФЛПРК) у којој резултат у највећој мјери зависи од способности регулације тонуса антагониста задње ложе бута (која омогућава постизање максималне амплитуде покрета), за шта је у највећој мјери задужен механизам за регулацију тонуса и синергијску регулацију. С обзиром на то да прва два теста у својим реакцијама укључују мускулатуру руку и раменог појаса а произведена сила се преноси на вањске објекте који се под њеним дјеловањем крећу у простору, док трећи тест укључује мускулатуру ногу при чему произведена сила резултира премјештањем тијела у простору, као и чињеницу да експлозивна снага утиче на брзину удараца, блокова, улазака за бацање, бацања, одбрану од захвата држања, одбрану од бацања и раскидање противниковог гарда, затим на брзину улазака у противника при разним врстама напада, за избјегавање напада, брзину одбрана од удараца, хватова и држања (Милошевић и сараданици 2005), док флексибилност трупа утиче на ефикасност реализације техника бацања и полуга које се изводе уз наглашени претклон тијела према напријед као и техника бацања које се изводе увинућем према назад, те чињеницу да највећу пројекцију на овај фактор има варијабла МФЕБРЛ (у чијој основи је краткотрајна мишићна контракција изазвана максималном величином ексцитације из ЦНС-а, за шта је у највећој мјери одговоран механизам за регулацију интензитета ексцитације) и овај фактор је могуће дефинисати као фактор интензитета ексцитације. 
Сличне резултате добили су Схакири, Лолић, Адеми, Саити и Костовски, (2013) који су на узорку од 80 испитаника спровели истраживање са основним циљем утврђивања структуре базично-моторичког статуса џудиста кадетског узраста. Примјеном факторске анализе утвдили су 6 фактора који дефинишу структуру базично моторичког простора а које су дефинисали као: 1. фактор механизма синергијске регулације и регулације тонуса; 2. фактор регулације трајања ексцитације и структурисања кретања; 3 . фактор регулације и интензитета ексцитације; 4. фактор регулације трајање ексцитације и структурисања кретања; 5 . фактор синергијске регулације и регулације тонуса (представљен мјерама равнотеже), док шести фактор због сложености карактера нису успјели дефинисати.

Анализирајући матрицу интеркорелација изолованих главних компоненти (Табела 6) може се видјети да је статистички значајна слаба корелација добијена само између механизма за регулацију трајања ексцитације (представљеног на основу мјера за процјену репетитивне и статичке снаге) и механизма за регулацију интензитета ексцитације (представљеног на основу мјера за процјену експлозивне снаге). Овоме иде у прилог и констатација да ова два механизма заједнички творе један генерални фактор који су Гредељ и сарадници (1975) назвали механизмом енергетске регулације (при чему се дјеловање првог регулационог механизма манифестује у количини моторичког рада односно трајању напрезања мишића, док је други регулациони механизам одговоран за величину силе развијену у јединици времена). Између осталих фактора није утврђена статистички значајна повезаност. Такође, наведене чињенице поткрепљују и резултати истраживања из СФО-а која су провели Божић, Милошевић и Зулић (1990) и Благојевић и сарадници (1994), у којима је утврђено да квалитет формирања склопова базичних и изведених алгоритама код структурисања програма у СФО-у зависи од квалитета перцепције лонгитудиналних димензионалности и моторичке едукатибилности, при чему информациони процеси доминирају у првој и другој фази, док се у трећој фази дешава интензивније динамичко структурисање моторичких програма у којима до изражаја долазе контрактилна својства мишића, што се види по утицају динамичке снаге горњих екстремитета и трупа.

\section{ЗАКљУЧАК}

На узорку од 84 испитаника, споведено је истраживање са основним циљем утврђивања структуре базично-моторичког статуса студената Факултета безбједносних наука из Бањалуке. Примјеном факторске анализе по Кајзер-Гутмановом критеријуму утврђено је 6 латентних моторичких фактора. Први фактор дефинисан је као фактор механизма за структурирање кретања. Други фактор дефинисан је као фактор механизма регулације трајања ексцитације. Трећи фактор дефинисан је као фактор механизма за регулацију тонуса и синергијску регулацију. Четврти фактор дефинисан је 
као фактор механизма интензитета ексцитације. Пети фактор је такође дефинисан као фактор синергијске регулације и регулације тонуса, док је шести фактор исто дефинисан као фактор интензитета ексцитације.

На основу резултата факторске анализе, урађене на моторичком простору, може се дефинисати модел моторичких способности студената Факултета безбједносних наука са сљедећим обликом:

$$
M=0.17 \Phi 1+0.14 \Phi 2+0.10 \Phi 3+0.08 \Phi 4+0.07 \Phi 5+0.06 \text { Ф6 гдје је: }
$$

M - модел моторичких карактеристика, $\Phi 1$ - фактор механизма за структурирање кретања (представљен на основу мјера за процјену координације и фреквенције покрета), $\$ 2$ - фактор механизма за регулацију трајања ексцитације (представљен на основу мјера за процјену репетитивне и статичке снаге), Ф3 - фактор механизма за регулацију тонуса и синергијску регулацију (представљен на основу мјера за процјену флексибилности), $\Phi 4$ - фактор механизма за интензитет ексцитације (представљен на основу мјера за процјену експлозивне снаге кроз способност брзине трчања), Ф5 - фактор механизма за синергијску регулацију и регулацију тонуса (представљен на основу мјера за процјену равнотеже) и $\Phi 6$ - фактор механизма за интензитет ексцитације (представљен на основу мјера за процјену експлозивне снаге).

С обзиром на то да будући радници безбједносних послова могу да обављају опасне и сложене послове, веома је важно да имају и оптималне способности које би могле допринијети успјешном обављању професионалних задатака. Због значаја које моторичке способности заузимају у систему селекције, обуке, школовања и контроле њиховог нивоа, а у циљу побољшања радних способности полицијских службеника и радника у другим безбједносним агенцијама, јавља се потреба за сталним развојем и усавршавањем програма обуке и начина за утврђивање достигнутог нивоа општих и специфичних моторичких способности (Anderson, Plecas \& Segger 2001; Допсај и Вучковић, 2006; Допсај, Благојевић и Вучковић, 2007; Strating, et al. 2010; Вучковић, Благојевић и Допсај, 2011). Због свега наведог потребно је да се процесу наставе поклони одређена пажња, којом приликом поред учења и савладавања основних елемената технике и њихових веза предвиђених наставним садржајем из програма СФО-а, треба да се утиче и на избор и формирање моделских карактеристика сваког појединца, како би будући радници безбједносних послова били успјешни у својој професији. Резулати овог истраживања отварају простор за даља истраживања и са другим батеријама тестова, које би могле допринијети квалитетнијем избору кандидата и квалитетнијој реализацији наставног процеса па самим тим и квалитетнијем кадру у области безбједносних послова. 


\section{ЛИТЕРАТУРА}

Anderson, S.G., Plecas, D., \& Segger, T. (2001). Police officer physical ability testing. Revalidating a selection criterion. Policing: An International Journal of Police Strategies \& Management, 24(1), 8-31.

Благојевић, М., ћирковић, З., Милошевић, М., Стојичић, Р., Јовановић, С., Арлов, Д. \& Допсај, М. (1994), Утицај неких адаптационих карактеристика приправника милиционара на ефекте учења моторичких алгоритама и програма у Специјалном физичком образовању, зборник радова првог савјетовања из Специјалног физичког образовања Полицијске академије у Београду, 49-56.

Благојевић, М. (1996). Утицај морфолошких и моторичких карактеристика полицајаца на ефикасност учења џудо техника, Полицијска академија Београд, Београд.

Благојевић, М., Допсај, М. \& Вучковцић, Г. (2006), Специјално физичко образовање 1 за студенте Поличијске академије , Инпресс- Београд, Београд.

Божић, С. Милошевић, М. \& Зулић, М. (1990). Утицај неких антрополошких карактеристика радника на структурирање моторичких алгоритама у Специјалном физичком образовању. Београд. 13. Мај, (2), 128 - 135.

Вучковић, Г. (2002). Утицај моторичких способности на ефикасност савладавања ситуационог пиштољског полигона код студената Полицијске академије. Магистарска теза, Београд. Факултет спорта и физичког васпитања Универзитета у Београду.

Вучковић, Г., Благојевић, М. \& Допсај, М. (2011). Специјално физичко образовање 2. Београд: Криминалистичко-полицијска академија.

Гредељ, М., Метикош, Д., Хошек, А. \& Момировић, К. (1975). Модел хијерархијске структуре моторичких способности, 1. резултати добијени примјеном једног неокласичног поступка за процјену латентних димензија. Кинезиологија, 5(1-2), 7-81.

Допсај, М., Милошевић, М., Благојевић, М. \& Вучковић, Г. (2002). Евалуација ваљаности тестова за процену контрактилног потенцијала мишића руку код полицајаца. Безбедност, 44(3), 434-444.

Допсај, М. \& Вучковић, Г. (2006). Показатељи максималне силе прегибача леве и десне шаке у функцији селекционог критеријума за потребе полиције. Спорт Монт, 4(10-11), 148-154.

Допсај, М; Благојевић, М. \& Вучковић, Г. (2007). Нормативно-селекциони критеријум за процену базично моторичког статуса кандидата за пријем на студије Криминалистичко-полицијске академије у Београду, Безбедност, 49(4), 166-183. 
Ђорђевић, Д. (1989). Опита антропомоторика. Београд. Факултет за физичку културу Универзитета у Београду.

Зациорски (1975). Физичка својства спортисте. Савез за физичку културу Југославије. Београд, 1975.

Јанковић, Р. \& Димитријевић, Р. (2012). Стање и могућности унапређења начина процене моторичких способности у систему Министарства унутрашњих послова Републике Србије. Култура полиса, 9(1).

Кукољ, М. (1996). Опита антропомоторика. Београд. Факултет за физичку културу Универзитета у Београду.

Курелић, Н., Момировић, К., Стојановић, М., Штурм, Ј., Радојевић, Ђ. \& ВискићШталец, Н. (1975). Структура и развој морфолошких и моторичких димензија омладине. Институт за научна истраживања Факултета за физичко васпитање. Београд.

Метикош Д,. Хофман Е,. Прот Ф,. Пинтар Ж. \& Ореб Г. (1989). Мјерење базичних моторичких димензија спорташа, Факултет за Физичку културу, Загреб.

Милошевић, М. (1985). Одређивање структуре моторичких својстава милиционара, ВШУП. Београд,

Милошевић, М., Гавриловић, П. \& Иванчевић, Б. (1988). Моделирање и управљање системом самоодбране. Научна књига: Београд.

Милошевић,М., и Зулић, М. (1988). Утицај неких димензија снаге на ефикасност гађања из пиштоља.13.мај,41 (2), 89 - 92.

Милошевић, М., Мудрић, Р., Јовановић, С., Амановић, Ћ. \& Допсај, М. (2005). Конституисање система за управљање тренутним и кумулативним едукативним и тренажним ефектима у СФО-у. Монографија из истраживачког пројекта «Полиција у функцији безбједности и заштите у Србији на почетку XXI века“. ВШУП. Београд.

Strating, M., Bakker, R., Dijkstra, G., Lemmink, K., \& Groothoff, J.W. (2010). A jobrelated fitness test for the Dutch police. Occupational Medicine, 60, 255-260.

Схакири, К., Лолић, Д., Адеми, А., Саити, Б. \& Костовски, Ж. (2013). Структура варијабли за процјену базично-моторичких димензија код младих џудиста. Зборник радова са петог међународног конгреса „Антрополошки аспекти спорта, физичког васпитања и рекреације“"Вол. (5) 144 - 150. Факултет физичког васпитања и спорта Универзитета у Бањој Луци.

Рад примљен: 03. 12. 2018.

Рад прихваћен: 29. 03. 2019. 